\title{
DEFINICJA CSR WEDŁUG NORMY ISO 26000 A PRAKTYKA GOSPODARCZA
}

\section{WPROWADZENIE}

\begin{abstract}
Spośród wielu tematów, które są poruszane w ramach koncepcji społecznej odpowiedzialności przedsiębiorstw (SOP; ang. corporate social responsibility - CSR), jeden z kluczowych dotyczy dyskusji związanej z definicją CSR. Nie tylko liczba pojawiajacych się ujęć definicyjnych, ale i różne kluczowe zagadnienia w nich wskazywane ukazuja aktualność i zarazem potencjalna przydatność analizy tego zagadnienia. Dlatego też problemem badawczym omówionym w niniejszym artykule jest próba odpowiedzi na pytanie, w jakim stopniu zaproponowana w normie ISO 26000 definicja CSR jest realizowana przez przedsiębiorstwa w Polsce. Prezentacja problemu badawczego wskazuje na dwa zasadnicze cele, które pomoga odpowiedzieć na tak postawione pytanie. Po pierwsze, należy przedstawić definicję CSR zgodną z wymogami normy ISO 26000, po drugie - ukazać, czy i w jakim zakresie podmioty gospodarcze podejmuja się realizacji tych założeń w praktyce. Zestawienie wymogów definicyjnych z doświadczeniami pochodzącymi z praktyki gospodarczej może przynieść zbiór wskazówek, które pozwolą nakreślić aspekty CSR częściej i rzadziej implementowane w ramach prowadzonej działalności. Tak postawiony problem i cele badania charakteryzuja podejście przyjęte $\mathrm{w}$ ramach badań stosowanych. W niniejszym artykule podjęte prace maja charakter eksplanacyjny, w ramach których zastosowano metodę sondażu diagnostycznego z wykorzystaniem kwestionariusza ankiety jako narzędzia badawczego.
\end{abstract}

\section{DEFINICJA CSR WEDEUG NORMY ISO 26000 - OMÓWIENIE PROBLEMU BADAWCZEGO}

W 2005 r. Międzynarodowa Organizacja Normalizacyjna podjęła działania związane $\mathrm{z}$ opracowaniem międzynarodowej normy dotyczącej społecznej odpowiedzialności. W ramach realizacji tego zadania została powołana grupa robocza, skupiająca 450 ekspertów, 210 obserwatorów z 99 krajów członkowskich ISO oraz 42 organizacji powiązanych. Liczne grono ekspertów reprezentowało takie grupy interesariuszy, jak: przemysł, instytucje rządowe, konsumentów, pracowników, organizacje pozarządowe oraz usługi, wsparcie, 
badania, naukę. Prace nad normą zostały zakończone w 2010 r., czego efektem jest opublikowanie normy ISO 26000 Guidance on social responsibility. Polska wersja normy została opublikowana w 2012 r. (PN-ISO 26000:2012 Wytyczne dotyczace społecznej odpowiedzialności), jako efekt prac Komitetu Technicznego KT 305 ds. Społecznej Odpowiedzialności ${ }^{1}$.

Można zapytać o powód wybrania normy ISO 26000 jako dokumentu stanowiącego podstawę analizy definicyjnej społecznej odpowiedzialności przedsiębiorstw. Istotne znaczenie zapewne ma fakt zawartego we wspomnianej normie kompromisu, który skutecznie udało się wypracować wśród tak szerokiego i zróżnicowanego grona ekspertów. Dodatkowym atutem jest międzynarodowość normy, przejawiająca się w jej ogólnej dostępności dla każdego zainteresowanego podmiotu oraz rekomendowanie przez Komisję Europejska przedsiębiorstwom tej normy, jako jednego z trzech kluczowych dokumentów podczas wdrażania społecznej odpowiedzialności.

Dodatkowym umotywowaniem wyboru normy ISO 26000 do prowadzenia rozważań definicyjnych i ich konfrontacji z praktyka gospodarcza jest fakt istnienia luki poznawczej $\mathrm{w}$ tym aspekcie. Z dokonanej analizy dotychczasowych opracowań literaturowych wynika, że od 2010 (rok opublikowania normy) do 2017 r. normę ISO 26000 omawiano w 212 artykułach naukowych ${ }^{2}$. Głównymi obszarami rozważań była m.in. problematyka raportowania $^{3}$, wpływu i roli interesariuszy ${ }^{4}$, wpływu i związku z zarządza-

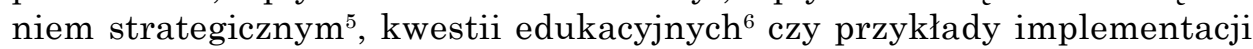
CSR z wykorzystaniem ISO $26000^{7}$. W jednym z artykułów podjęto kwestię definicji CSR; jego autor skoncentrował się na definicji społecznej odpowiedzialności biznesu prezentowanej w normie ISO 26000, konfrontując ją z innymi współczesnymi interpretacjami tego pojęcia ${ }^{8}$. W konkluzji tego opracowania autor wskazał na wyraźnie moralna perspektywę CSR prezentowaną w normie ISO 26000 w odróżnieniu od obecnie dominujących, instrumentalnych ujęć CSR omówionych także w tym artykule. Nawiązanie do definicji CSR według normy ISO 26000 będące kluczowym obszarem

${ }^{1}$ Zob. https://www.pkn.pl/informacje/2013/09/iso-26000 [dostęp: 19.06.2017].

${ }^{2} \mathrm{Na}$ podstawie informacji uzyskanych dzięki multiwyszukiwarce opracowań naukowych Biblioteki Głównej Uniwersytetu Ekonomicznego we Wrocławiu [dostęp: 27.06.2017].

${ }^{3}$ S. P. Sethi, J. L. Rovenpor, M. Demir, Enhancing the quality of reporting in corporate social responsibility guidance documents: the roles of ISO 26000, Global Reporting Initiative and CSRSustainability Monitor, „Business and Society Review” 122(2), 2017, s. 139-163.

${ }^{4}$ M. A. Balzarova, P. Castka, Stakeholders' influence and contribution to social standards development: the case of multiple stakeholder approach to ISO26000 development, „Journal of Business Ethics" 111(2), 2012, s. 265-279.

${ }^{5}$ R. Hahn, ISO 26000 and the Standardization of Strategic Management Processes for Sustainability and Corporate Social Responsibility, „Business Strategy and the Environment” 22(7), 2013, s. 442-455.

${ }^{6}$ L. Moratis, ISO 26000: three CSR messages for management education, „Journal of Corporate Citizenship" 2014, nr 53, s. 77-90.

${ }^{7}$ A. Toppinen et al., Standardizing social responsibility via ISO 26000: empirical insights from the forest industry, „Sustainable Development” 23(3), 2015, s. 153-166.

${ }^{8}$ L. Moratis, Out of the ordinary? Appraising ISO 26000's CSR definition, „International Journal of Law and Management" 58(1), 2016, s. 26-47. 
zainteresowań wspomnianego artykułu pozwala na przyjęcie założenia, że problem ten wart jest dalszej eksplanacji, szczególnie z uwagi na fakt, że do tej pory nie została podjęta próba konfrontacji założeń definicyjnych z ich realizacją w praktyce gospodarczej.

Zgodnie z definicją prezentowaną przez Międzynarodową Organizację Normalizacyjna ISO 26000 społeczna odpowiedzialność jest rozumiana jako odpowiedzialność organizacji za wpływ podejmowanych decyzji i działań na społeczeństwo i środowisko, zapewnianą przez przejrzyste i etyczne postępowanie, które:

- przyczynia się do zrównoważonego rozwoju, w tym zdrowia i dobrobytu społeczeństwa,

- uwzględnia oczekiwania interesariuszy (osób lub grup, które są zainteresowane decyzjami lub działaniami organizacji),

- jest zgodne z obowiąującym prawem i spójne z międzynarodowymi normami postępowania,

- jest zintegrowane $\mathrm{z}$ działaniami organizacji i praktykowane $\mathrm{w}$ jej relacjach, które dotyczą działań organizacji podejmowanych w obrębie jej sfery oddziaływań ${ }^{9}$.

Powyższe cztery kryteria szczegółowe wyodrębnione we wspomnianej definicji CSR będą podstawą analizy prowadzonej w ramach badań empirycznych.

\section{PODSTAWY METODYCZNE WERYFIKACJI PROBLEMU BADAWCZEGO}

Do każdego kryterium wskazanego w definicji zostały przyporządkowane pytania umożliwiajace weryfikację postawionego problemu badawczego. Do problematyki zrównoważonego rozwoju nawiązano w pytaniu: „Czy w Państwa przedsiębiorstwie dokonuje się analizy i oceny wpływu, jaki firma wywiera na środowisko?" Drugie z wyodrębnionych kryteriów ma na celu uwzględnienie oczekiwań interesariuszy podczas podejmowanych działań w ramach prowadzonej działalności. Aby możliwe było uwzględnianie oczekiwań, przede wszystkim należy poznać oczekiwania badanej grupy, a dopiero w następnym kroku opracować (i następnie uczestniczyć) w projektach społecznych. Zgodnie zatem z logiczna kolejnością, badając realizację tego kryterium w praktyce gospodarczej, sformułowano dwa pytania. Pierwsze, sprawdzajace, czy w danym przedsiębiorstwie dokonuje się analizy potrzeb społecznych zgłaszanych przez najbliższe otoczenie przedsiębiorstwa, oraz drugie, weryfikujace, czy dana firma bierze udział w inicjatywach społecznych. Trzecie kryterium dotyczy zgodności z obowiązujacym prawem. Aby uniknać oczywistego pytania o przestrzeganie prawa, zdecydowano się za-

${ }^{9}$ International Organizaton for Standardization, ISO 26000 Spoteczna Odpowiedzialność, Switzerland 2010, s. 2. 
pytać o terminowość realizacji zobowiązań. Ponieważ mogą wystapić różnice w stopniu realizacji spraw pracowniczych i dostawców/kontrahentów, weryfikacja realizacji tego kryterium została przeprowadzona przez dwa, niezależne pytania:

- Czy Państwa przedsiębiorstwo terminowo realizuje swoje zobowiązania wobec pracowników?

- Czy Państwa przedsiębiorstwo terminowo realizuje swoje zobowiązania wobec dostawców/kontrahentów?

Ostatnie kryterium - integracji działań zgodnych z koncepcją CSR w ramach danego podmiotu jest niewatpliwie bardzo trudnym zadaniem do implementacji. Wspomniana trudność może wystapić nie tylko podczas wdrażania przez przedsiębiorstwo koncepcji CSR, ale także w ramach sprawdzenia stopnia jej realizacji. Dlatego też do weryfikacji tego kryterium sformułowano dwa pytania. Jedno dotyczyło dokumentu porządkujacego wartości i sposób postępowania pracowników podczas codziennej działalności (opracowanie takiego dokumentu świadczyć może o przeprowadzonej dyskusji w ramach danego podmiotu, nadaniu priorytetów odpowiednim aspektom, a także włączeniu w plan strategiczny wyznaczonych zadań). Drugie pytanie dotyczyło uczestnictwa pracowników w akcjach wolontaryjnych.

$\mathrm{Na}$ bazie omówionych pytań zostało skonstruowane narzędzie badawcze. Warto podkreślić, że podczas badań empirycznych należy dążyć do optymalnego wyboru i pamiętać o możliwych niedoskonałościach danej metody i dokonać wszelkich starań, by możliwe mankamenty wynikające z zastosowanej metody nie rzutowały na przebieg badania i jakość uzyskanych informacji. Biorąc pod uwagę cel przyjęty w ramach podjętych prac empirycznych (które swoim zasięgiem miały objać dużą próbę badawcza) oraz możliwość zestandaryzowania odpowiedzi, podjęto decyzję o wykorzystaniu metody sondażu diagnostycznego i kwestionariusza ankiety jako narzędzia badawczego.

Respondenci omawianego badania, odpowiadajac na pytania, wskazywali (zgodnie ze swoją wiedzą w danym momencie) odpowiedź, która stanowiła deklarację stanu lub podejmowanych inicjatyw w momencie badania. Idealna sytuacja byłoby, gdyby deklaracje te zostały następnie zweryfikowane przez niezależną osobę/jednostkę, która mogłaby dokonać potwierdzenia zadeklarowanych odpowiedzi. Wówczas możliwa byłaby minimalizacja opinii o deklaratywnym charakterze otrzymanych wyników.

W rezultacie przeprowadzonego badania uzyskano odpowiedzi od 386 podmiotów gospodarczych w Polsce ${ }^{10}$. Analiza otrzymanych wyników w ramach wyodrębnionych kryteriów definicyjnych CSR została uszczegółowiona ze

${ }_{10}$ Badanie zostało przeprowadzone między styczniem a kwietniem 2014 r., w ramach realizacji większego projektu naukowego. W celu realizacji wyznaczonego zadania została zakupiona baza danych podmiotów prowadzących działalność gospodarcza. Po wstępnym opracowaniu danych (wyeliminowaniu niektórych błędnych adresów lub powtarzających się), zaproszenie do udziału w badaniu zostało rozesłane do 38390 podmiotów. Zaproszenie to przyjęło i ankietę wypełniło 386 przedsiębiorstw. Szczegółowy opis metodyki badawczej znajduje się w: M. Rojek-Nowosielska, Corporate social responsibility level-theoretical approach, „Management” 18(1), 2014. 
względu na wielkość przedsiębiorstwa. Podział ten został dokonany zgodnie z kryterium liczby zatrudnionych pracowników na podstawie umowy o pracę, mianowania, powołania lub wyboru.

\section{REALIZACJA ZAŁOŻEŃ DEFINICYJNYCH CSR W PRAKTYCE}

Biorąc pod uwagę pierwsze z wyodrębnionych kryteriów - zrównoważonego rozwoju, można zaobserwować, że zdecydowana większość (ponad 60\% respondentów) zadeklarowała, że nie prowadzi działań mających na celu analizę i ocenę wpływu, jaki firma wywiera na środowisko (tab. 1).

\section{Tabela 1}

Realizacja kryterium zrównoważonego rozwoju (pytanie: Czy dokonuje się analizy i oceny wpływu, jaki firma wywiera na środowisko?) (w\%)

\begin{tabular}{|l|c|c|c|c|c|}
\hline $\begin{array}{c}\text { Wielkość } \\
\text { przedsię- } \\
\text { biorstwa }\end{array}$ & $\begin{array}{c}\text { Nie, nie pro- } \\
\text { wadzimy } \\
\text { takich działań }\end{array}$ & $\begin{array}{c}\text { Tak, bo jest } \\
\text { to opłacalne } \\
\text { ekonomicznie }\end{array}$ & $\begin{array}{c}\text { Tak, zależy } \\
\text { nam na do- } \\
\text { brym wize- } \\
\text { runku firmy }\end{array}$ & $\begin{array}{c}\text { Tak, to ważne, } \\
\text { by chronić } \\
\text { środowisko }\end{array}$ & Lącznie \\
\hline do 9 osób & 70,1 & 2,8 & 7,0 & 20,1 & 100 \\
\hline $10-49$ osób & 64,2 & 7,5 & 11,9 & 16,4 & 100 \\
\hline $50-249$ osób & 42,9 & 14,3 & 12,5 & 30,4 & 100 \\
\hline $\begin{array}{l}\text { powyżej } \\
250 \text { osób }\end{array}$ & 35,4 & 10,4 & 22,9 & 31,3 & 100 \\
\hline $\begin{array}{l}\text { udział } \\
\text { łącznie }\end{array}$ & 60,8 & 6,2 & 10,6 & 22,3 & 100 \\
\hline
\end{tabular}

Źródło: opracowanie własne.

Poza ogólnym dominującym wynikiem dla wszystkich podmiotów należy zwrócić uwagę jeszcze na dwie kwestie. Po pierwsze, spośród odpowiedzi pozytywnych najwięcej wskazań otrzymała odpowiedź, która świadczy o dobrze rozwiniętym poziomie świadomości w danym obszarze tematycznym. Jeśli przedsiębiorstwa podejmuja się trudu analizy i oceny swojego wpływu na środowisko, to czynią to $\mathrm{w}$ głównej mierze nie $\mathrm{z}$ powodów opłacalności ekonomicznej czy wizerunkowej, ale ze względu na istotę podejmowanych działań. Po drugie, warto zwrócić uwagę na przedsiębiorstwa duże (powyżej 250 pracowników), których odpowiedzi pozytywne świadczące o dużym zrozumieniu wagi danego problemu oraz zdecydowanie negatywne różnią się zaledwie o kilka punktów procentowych. Może to wskazywać na relatywnie większa świadomość istoty kwestii środowiskowych tych podmiotów lub/i większe wymogi i zarazem oczekiwania, jakie są stawiane wobec tych podmiotów zarówno przez instytucje publiczne, jak i społeczności lokalne. 
Aspekt analizy potrzeb społecznych dokonywanych przez przedsiębiorstwo, badany w ramach oczekiwań interesariuszy, zgodnie z przedstawionymi wynikami badań przez większość badanych podmiotów (57,9\% wskazań) nie jest realizowany (tab. 2 ).

\section{Tabela 2}

Realizacja kryterium oczekiwań interesariuszy (1)

(pytanie: Czy dokonuje się analizy potrzeb społecznych zgłaszanych przez najbliższe otoczenie?) (w\%)

\begin{tabular}{|l|c|c|c|c|c|}
\hline $\begin{array}{c}\text { Wielkość } \\
\text { przedsię- } \\
\text { biorstwa }\end{array}$ & $\begin{array}{c}\text { Nie, nie prowa- } \\
\text { dzimy takich } \\
\text { działań }\end{array}$ & $\begin{array}{c}\text { Tak, bo jest to } \\
\text { opłacalne } \\
\text { ekonomicznie }\end{array}$ & $\begin{array}{c}\text { Tak, zależy } \\
\text { nam na do- } \\
\text { brym wizerun- } \\
\text { ku firmy }\end{array}$ & $\begin{array}{c}\text { Tak, jako } \\
\text { uczestnik życia } \\
\text { gospodarczego } \\
\text { powinniśmy } \\
\text { znać potrzeby } \\
\text { spoleczności }\end{array}$ & Lącznie \\
\hline do 9 osób & 64,5 & 5,1 & 10,7 & 19,6 & 100 \\
\hline $10-49$ osób & 53,7 & 0,0 & 19,4 & 26,9 & 100 \\
\hline $50-249$ osób & 51,8 & 1,8 & 26,8 & 19,6 & 100 \\
\hline $\begin{array}{l}\text { powyżej } \\
250 \text { osób }\end{array}$ & 41,7 & 8,3 & 20,8 & 29,2 & 100 \\
\hline $\begin{array}{l}\text { udział } \\
\text { łącznie }\end{array}$ & 57,9 & 4,2 & 15,8 & 22,1 & 100 \\
\hline
\end{tabular}

Źródło: opracowanie własne.

Drugą w kolejności najczęściej wskazywaną odpowiedzią (22,1\% zaznaczeń) jest odpowiedź twierdząca: „Tak, jako uczestnik życia gospodarczego powinniśmy znać potrzeby społeczne”. Spośród trzech pozytywnych odpowiedzi możliwych do wybrania ta, którą wybrało najwięcej respondentów, świadczy o wysokim zrozumieniu problemu. Zdecydowanie mniej wskazań badanych podmiotów dotyczyło motywacji ekonomicznej czy wizerunkowej. Jedynie wśród firm średnich (zatrudniajacych od 50 do 249 pracowników) na drugim miejscu najczęściej wskazywanych odpowiedzi wyjaśniających podejmowanie się analizy potrzeb społecznych znalazło się wskazanie na motywy wizerunkowe (prawie 27\% respondentów tej kategorii udzieliło takiej odpowiedzi).

$\mathrm{W}$ pytaniu dotyczącym uczestnictwa przedsiębiorstw w projektach społecznych najwięcej odpowiedzi wśród ogółu podmiotów uczestniczących w badaniu wskazuje, że przedsiębiorstwa nie angażowały się w projekty społeczne $(38,4 \%$ badanych; tab. 3). Należy jednocześnie zwrócić uwagę, że tylko kilka punktów procentowych mniej otrzymała odpowiedź wskazująca udział firm w zainicjowanych projektach społecznych $(35,8 \%$ respondentów potwierdziło taką aktywność).

Ciekawe spostrzeżenia przynosi analiza wyników w poszczególnych kategoriach przedsiębiorstw wyodrębnionych ze względu na liczbę pracowników. Wraz ze wzrostem liczby zatrudnionych zmienia się stopień zaangażowania przedsiębiorstw w inicjatywy społeczne. W mikroprzedsiębiorstwach dominująca odpowiedź wskazuje na brak zaangażowania w projekty społeczne 
(48,6\% badanych), podczas gdy firmy małe i średnie uczestniczą w inicjatywach społecznych jako podmiot zaproszony do współpracy (odpowiednio 47,8\% i $48,2 \%$ respondentów). Zdecydowana większość dużych przedsiębiorstw (56,3\% badanych) jest pomysłodawca i realizatorem takich inicjatyw. Z przedstawionych danych można zaproponować wniosek wskazujacy zależność wielkości przedsiębiorstwa od możliwości wystapienia z inicjatywą i późniejszej realizacji podejmowanych projektów społecznych.

Tabela 3

Realizacja kryterium oczekiwań interesariuszy (2)

(pytanie: Czy firma bierze udział w projektach społecznych?) (w\%)

\begin{tabular}{|l|c|c|c|c|}
\hline $\begin{array}{c}\text { Wielkość } \\
\text { przedsię- } \\
\text { biorstwa }\end{array}$ & $\begin{array}{c}\text { Nie, nie mieliśmy } \\
\text { możliwości zaanga- } \\
\text { żowania się }\end{array}$ & $\begin{array}{c}\text { Tak, zostaliśmy po- } \\
\text { proszeni o wsparcie }\end{array}$ & $\begin{array}{c}\text { Tak, jesteśmy pomy- } \\
\text { słodawcą } \\
\text { i realizatorem }\end{array}$ & Lącznie \\
\hline do 9 osób & 48,6 & 30,4 & 21,0 & 100 \\
\hline $10-49$ osób & 34,3 & 47,8 & 17,9 & 100 \\
\hline $50-249$ osób & 25,0 & 48,2 & 26,8 & 100 \\
\hline $\begin{array}{l}\text { powyżej } \\
250 \text { osób }\end{array}$ & 14,6 & 29,2 & 56,3 & 100 \\
\hline $\begin{array}{l}\text { udział } \\
\text { łącznie }\end{array}$ & 38,4 & 35,8 & 25,7 & 100 \\
\hline
\end{tabular}

Źródło: opracowanie własne.

Trzecie kryterium definiujące społeczną odpowiedzialność dotyczy zgodności działań z obowiązującymi przepisami prawa. Pierwsze pytanie weryfikujące jego realizację dotyczy zobowiązań wobec pracowników (tab. 4).

\section{Tabela 4}

Realizacja kryterium zgodności z prawem (1)

(pytanie: Czy firma terminowo realizuje swoje zobowiązania wobec pracowników?) (w\%)

\begin{tabular}{|l|c|c|c|c|c|}
\hline $\begin{array}{c}\text { Wielkość } \\
\text { przedsię- } \\
\text { biorstwa }\end{array}$ & $\begin{array}{c}\text { Nie, z różnych } \\
\text { powodów zo- } \\
\text { bowiązania nie } \\
\text { były realizowa- } \\
\text { ne terminowo }\end{array}$ & $\begin{array}{c}\text { Tak, wynika to } \\
\text { ze zobowiązań } \\
\text { formalnopraw- } \\
\text { nych firmy } \\
\text { wobec pracow- } \\
\text { ników }\end{array}$ & $\begin{array}{c}\text { Tak, wynika to } \\
\text { z konieczności } \\
\text { kreowania do- } \\
\text { brego wizerun- } \\
\text { ku firmy na } \\
\text { rynku pracy }\end{array}$ & $\begin{array}{c}\text { Tak, wynika to } \\
\text { potrzeby by- } \\
\text { cia uczciwym } \\
\text { podmiotem } \\
\text { gospodarczym }\end{array}$ & Lacznie \\
\hline do 9 osób & 8,4 & 14,0 & 7,5 & 70,1 & 100 \\
\hline $10-49$ osób & 4,5 & 29,9 & 9,0 & 56,7 & 100 \\
\hline $50-249$ osób & 3,6 & 39,3 & 12,5 & 44,6 & 100 \\
\hline $\begin{array}{l}\text { powyżej } \\
250 \text { osób }\end{array}$ & 4,2 & 33,3 & 20,8 & 41,7 & 100 \\
\hline $\begin{array}{l}\text { udział } \\
\text { łącznie }\end{array}$ & 6,5 & 22,9 & 10,1 & 60,5 & 100 \\
\hline
\end{tabular}

Źródło: opracowanie własne. 
Zdecydowana większość wszystkich badanych podmiotów zadeklarowała terminowa realizację swoich zobowiązań wobec tej grupy osób (93,5\% respondentów). Dodatkowo warto podkreślić, że spośród trzech odpowiedzi wskazujących na przestrzeganie przepisów prawa zdecydowanie dominujące motywy takiego postępowania zostały przypisane potrzebie bycia uczciwym podmiotem gospodarczym.

Nieco mniej optymistyczne wyniki dają się zauważyć przy odpowiedziach dotyczacych terminowej realizacji zobowiązań wobec dostawców/kontrahentów (tab. 5). Prawie $20 \%$ ogółu wskazań dotyczy deklaracji nierealizowania swoich zobowiązań terminowo wobec tej grupy interesariuszy.

Tabela 5

Realizacja kryterium zgodności z prawem (2)

(pytanie: Czy firma terminowo realizuje swoje zobowiązania wobec dostawców/kontrahentów?) (w\%)

\begin{tabular}{|l|c|c|c|c|c|}
\hline $\begin{array}{c}\text { Wielkość } \\
\text { przedsię- } \\
\text { biorstwa }\end{array}$ & $\begin{array}{c}\text { Nie, z różnych } \\
\text { powodów zo- } \\
\text { bowiązania nie } \\
\text { były realizowa- } \\
\text { ne terminowo }\end{array}$ & $\begin{array}{c}\text { Tak, wynika to } \\
\text { ze zobowiązań } \\
\text { formalnopraw- } \\
\text { nych }\end{array}$ & $\begin{array}{c}\text { Tak, wynika to } \\
\text { z konieczności } \\
\text { kreowania } \\
\text { dobrego wize- } \\
\text { runku }\end{array}$ & $\begin{array}{c}\text { Tak, wynika to } \\
\text { z potrzeby by- } \\
\text { cia uczciwym } \\
\text { podmiotem } \\
\text { gospodarczym }\end{array}$ & Lącznie \\
\hline do 9 osób & 17,8 & 10,3 & 15,9 & 56,1 & 100 \\
\hline $10-49$ osób & 26,9 & 16,4 & 11,9 & 44,8 & 100 \\
\hline $50-249$ osób & 28,6 & 25,0 & 7,1 & 39,3 & 100 \\
\hline $\begin{array}{l}\text { powyżej } \\
250 \text { osób }\end{array}$ & 8,3 & 47,9 & 8,3 & 35,4 & 100 \\
\hline $\begin{array}{l}\text { udział } \\
\text { łącznie }\end{array}$ & 19,7 & 18,2 & 13,0 & 49,1 & 100 \\
\hline
\end{tabular}

Źródło: opracowanie własne.

Pomimo stosunkowo dużej liczby odpowiedzi negatywnych należy zauważyć przewage pozytywnych. Wśród ogólu podmiotów uczestniczących w badaniu prawie 50\% respondentów wskazało odpowiedź świadczącą nie tylko o terminowym realizowaniu swoich zobowiązań, ale wskazało jednocześnie, że motywem była potrzeba bycia uczciwym podmiotem gospodarczym. Z analizy otrzymanych wyników ze względu na liczbę zatrudnionych pracowników wynika, że podmioty mikro, małe i średnie najczęściej deklarowały odpowiedź potwierdzającą terminowość w realizacji zobowiązań motywowana potrzeba bycia uczciwym podmiotem (odpowiednio 56,1\%, $44,8 \%$ i $39,3 \%$ badanych). Tylko podmioty duże (zatrudniające powyżej 250 pracowników), dając odpowiedź pozytywna, wskazały w zdecydowanej większości na motywy wynikające ze zobowiązań formalnoprawnych (47,9\% badanych w tej kategorii). Można więc przypuszczać, że kierowanie dużym podmiotem nakłada więcej zobowiązań formalnoprawnych, stąd kwestię wywiązywania się z tak ustanowionych wymogów traktuja po prostu jak kolejną formalność do dopełnienia. Być może w mniejszych firmach jest większa możliwość poznania współpracowników i istnieje 
większe prawdopodobieństwo wystapienia bezpośrednich relacji, stąd motywy dotrzymywania zobowiązań stają się bardziej „osobiste” niż formalne. Przykład ten inspiruje do dalszych przemyśleń o celowość tworzenia obligatoryjnych powinności na polu społecznych inicjatyw sensu stricto (niewymuszonych do tej pory regułami formalnymi). Można zadać pytanie o motywy i zakres zaangażowania się w działanie, które nie wynika $\mathrm{z}$ wewnętrznej potrzeby lub sugestii społeczności lokalnych, a staje się formalnym obowiązkiem będącym podstawą systematycznego rozliczania w świetle ustanowionych norm.

Ostatnie kryterium definicyjne CSR dotyczy integracji działań w ramach danego podmiotu. Analiza wyników badania, w którym pytanie dotyczyło istnienia dokumentu porządkującego wartości i sposób postępowania pracowników podczas codziennej działalności, pozwala zauważyć, że wśród ogółu przebadanych podmiotów w zdecydowanej większości (zgodnie z wyrażonymi w kwestionariuszu deklaracjami) nie istnieje taki dokument, a pracownicy podczas zaistnienia ewentualnych trudności bazują na zdobytym wcześniej doświadczeniu (53,5\% uzyskanych odpowiedzi; tab. 6).

Tabela 6

Realizacja kryterium integracji działań w ramach danego podmiotu (1)

(pytanie: Czy istnieje dokument, który porządkuje wartości i sposób postępowania pracowników podczas codziennej działalności?) (w\%)

\begin{tabular}{|c|c|c|c|c|c|c|}
\hline $\begin{array}{l}\text { Wielkość } \\
\text { przedsię- } \\
\text { biorstwa }\end{array}$ & $\begin{array}{c}\text { Nie, nie } \\
\text { istnieje; } \\
\text { pracownicy } \\
\text { sami decy- } \\
\text { dują } \\
\text { o sposobie } \\
\text { postępowa- } \\
\text { nia }\end{array}$ & $\begin{array}{c}\text { Nie, nie } \\
\text { istnieje } \\
\text { - pracowni- } \\
\text { cy bazują na } \\
\text { zdobytym } \\
\text { wcześniej } \\
\text { doświadcze- } \\
\text { niu }\end{array}$ & $\begin{array}{c}\text { Tak, istnieje } \\
\text { spisany } \\
\text { dokument }\end{array}$ & $\begin{array}{c}\text { Tak, istnieje } \\
\text { spisany do- } \\
\text { kument oraz } \\
\text { miary }\end{array}$ & $\begin{array}{c}\text { Tak, istnieje } \\
\text { spisany } \\
\text { dokument, } \\
\text { a na podsta- } \\
\text { wie przepro- } \\
\text { wadzonej } \\
\text { oceny sku- } \\
\text { teczności } \\
\text { wprowa- } \\
\text { dzane są } \\
\text { stosowne } \\
\text { zmiany }\end{array}$ & $\begin{array}{c}\text { Lącz- } \\
\text { nie }\end{array}$ \\
\hline do 9 osób & 29,9 & 55,6 & 8,4 & 1,4 & 4,7 & 100 \\
\hline $\begin{array}{l}10-49 \\
\text { osób }\end{array}$ & 20,9 & 56,7 & 10,4 & 9,0 & 3,0 & 100 \\
\hline $\begin{array}{l}50-249 \\
\text { osób }\end{array}$ & 19,6 & 58,9 & 16,1 & 3,6 & 1,8 & 100 \\
\hline $\begin{array}{l}\text { powyżej } \\
250 \text { osób }\end{array}$ & 6,3 & 33,3 & 35,4 & 4,2 & 20,8 & 100 \\
\hline $\begin{array}{l}\text { udział } \\
\text { łącznie }\end{array}$ & 23,9 & 53,5 & 13,2 & 3,4 & 6,0 & 100 \\
\hline
\end{tabular}

Źródło: opracowanie własne.

Analiza udzielonych odpowiedzi wśród podmiotów podzielonych ze względu na wielkość zatrudnienia wskazuje, że dominująca odpowiedź wśród przedsiębiorstw mikro, małych i średnich jest zbieżna z ogólnym wskazaniem informu- 
jącym, że dokumentu nie ma, a pracownicy korzystają ze zdobytego doświadczenia. Jedynie duże firmy $\mathrm{w}$ większości zadeklarowały, że taki dokument istnieje (35,4\% respondentów tej kategorii). Potwierdza to ogólnie przyjęte założenie, że działania podejmowane w ramach społecznej odpowiedzialności $\mathrm{w}$ dużych podmiotach są nieco bardziej zinstytucjonalizowane niż w podmiotach mniejszych.

Ostatnie pytanie weryfikujące realizację założeń definicyjnych CSR według normy ISO 26000 dotyczy uczestnictwa pracowników w akcjach wolontaryjnych (tab. 7).

Tabela 7

Realizacja kryterium integracji działań w ramach danego podmiotu (2) (pytanie: Czy pracownicy uczestniczą w akcjach wolontaryjnych?) (w \%)

\begin{tabular}{|c|c|c|c|c|c|c|}
\hline $\begin{array}{l}\text { Wielkość } \\
\text { przedsię- } \\
\text { biorstwa }\end{array}$ & $\begin{array}{c}\text { Nie, nie } \\
\text { uczestniczą }\end{array}$ & $\begin{array}{c}\text { Tak, jest to } \\
\text { sporadycz- } \\
\text { ne zaanga- } \\
\text { żowanie }\end{array}$ & $\begin{array}{c}\text { Tak, } \\
\text { istnieją } \\
\text { procedury } \\
\text { regulujące } \\
\text { akcje wo- } \\
\text { lontaryjne }\end{array}$ & $\begin{array}{c}\text { Tak, istnie- } \\
\text { ją proce- } \\
\text { dury } \\
\text { oraz miary } \\
\text { weryfiku- } \\
\text { jące sku- } \\
\text { teczność } \\
\text { działań } \\
\text { w obszarze } \\
\text { wolonta- } \\
\text { riatu }\end{array}$ & $\begin{array}{c}\text { Tak, istnie- } \\
\text { ją proce- } \\
\text { dury, a na } \\
\text { podstawie } \\
\text { wyników } \\
\text { oceny } \\
\text { wprowa- } \\
\text { dzane są } \\
\text { zmiany } \\
\text { udoskona- } \\
\text { lające }\end{array}$ & Lącznie \\
\hline do 9 osób & 50,9 & 45,3 & 1,4 & 1,4 & 0,9 & 100 \\
\hline 10-49 osób & 41,8 & 58,2 & 0,0 & 0,0 & 0,0 & 100 \\
\hline 50-249 osób & 39,3 & 58,9 & 0,0 & 1,8 & 0,0 & 100 \\
\hline $\begin{array}{l}\text { powyżej } \\
250 \text { osób }\end{array}$ & 27,1 & 50,0 & 16,7 & 2,1 & 4,2 & 100 \\
\hline $\begin{array}{l}\text { udział } \\
\text { łącznie }\end{array}$ & 44,7 & 50,1 & 2,9 & 1,3 & 1,0 & 100 \\
\hline
\end{tabular}

Źródło: opracowanie własne.

Ogólne wskazanie otrzymanych wyników ukazuje, że większość badanych podmiotów jest sporadycznie zaangażowana w akcje wolontaryjne $(50,1 \%$ badanych). Niewiele mniej, gdyż aż 44,7\% ogółu respondentów stwierdziło, że nie uczestniczy w takich inicjatywach. Wynik ogólny dla wszystkich podmiotów uczestniczacych $\mathrm{w}$ badaniu jest w przypadku tego pytania odzwierciedleniem sytuacji w poszczególnych kategoriach podmiotów wyodrębnionych ze względu na liczbę zatrudnionych. Niewielka tylko różnica jest widoczna w mikroprzedsiębiorstwach, w których najwięcej odpowiedzi wskazuje brak uczestnictwa w akcjach wolontaryjnych (50,9\% badanych), a sporadyczny udział w tych inicjatywach deklaruje $45,3 \%$ badanych. 


\section{PODSUMOWANIE}

Celem autora niniejszego artykułu było określenie, w jakim stopniu zaproponowana w normie ISO 26000 definicja CSR jest realizowana przez przedsiębiorstwa w Polsce. W świetle przeprowadzonych badań należy stwierdzić, że trudno sformułować jednoznaczną odpowiedź. W zależności od wyodrębnionego kryterium daje się zauważyć zróżnicowany stopień realizacji definicji CSR w praktyce gospodarczej. Podsumowanie omówionych wyników rozpocząć należy od tych aspektów, które są w największym stopniu realizowane - przede wszystkim jest to kryterium zgodności z obowiązującym prawem. Zobowiązania wobec pracowników są realizowane na najwyższym możliwym poziomie przez zdecydowaną większość badanych podmiotów. Podobnie sytuacja wygląda w przypadku realizacji terminowych zobowiązań wobec dostawców/ kontrahentów, jedynie firmy duże, zatrudniające ponad 250 pracowników, potwierdzajac w zdecydowanej większości wywiązywanie się z terminowych zobowiązań, zadeklarowały jako dominujący motyw perspektywę formalnoprawna.

W przypadku kryterium zrównoważonego rozwoju dominujące wskazanie ukazało deklarację nieprowadzenia analizy i oceny wpływu, jaki firma wywiera na środowisko, jednakże drugim najczęstszym wskazaniem była odpowiedź sugerująca najwyższy stopień realizacji - czyli podejmowanie takich prac, które motywowane były potrzebą ochrony środowiska.

Oczekiwania interesariuszy jako kolejne kryterium definicyjne CSR zostało w jednym aspekcie (udziału w inicjatywach społecznych) zrealizowane na dobrym poziomie (wraz ze wzrostem wielkości przedsiębiorstwa rośnie poziom zaangażowania w inicjatywy społeczne). Kolejne miejsce w stopniu realizacji założeń definicyjnych należy przypisać działaniom prowadzącym do zintegrowania i praktykowania założeń koncepcji CSR w ramach całego przedsiębiorstwa. Z punktu widzenia zaangażowania w akcje wolontaryjne większość badanych podmiotów wykazuje sporadyczne podjęcie takich inicjatyw (przy czym podmioty zatrudniające mniej niż 9 pracowników nie uczestniczyły w takich akcjach). Widoczne trudności w opracowaniu lub brak takiej potrzeby ukazują odpowiedzi na pytanie o dokument porządkujący wartości i sposób postępowania pracowników. W większości badanych podmiotów (zgodnie z otrzymanymi deklaracjami) nie istnieje taki dokument, a pracownicy podczas codziennej działalności korzystają ze zdobytego doświadczenia (tylko podmioty zatrudniające więcej niż 250 pracowników zadeklarowały istnienie takiego dokumentu).

Najniższym stopniem realizacji charakteryzuje się drugi z badanych aspektów kryterium definicyjnego CSR dotyczacy realizacji oczekiwań interesariuszy. Zdecydowana większość badanych podmiotów zadeklarowała, że nie prowadzi działań mających na celu analizę potrzeb społecznych zgłaszanych przez najbliższe otoczenie przedsiębiorstwa. 


\section{THE CSR DEFINITION ACCORDING TO ISO 26000 VERSUS ECONOMIC PRACTICE}

\section{Sum mary}

The research problem discussed in the article is an attempt to answer the question of how much the CSR (Corporate Social Responsibility) definition proposed in ISO 26000 standard is implemented by companies in Poland. The considerations carried out in this paper correspond to the approach specific to the framework of the applied research. The undertaken work was of an explanatory nature, under which the diagnostic survey method and the questionnaire with closed-ended questions as a research tool was used. Referring to the four criteria of CSR definition identified in the ISO 26000 standard, an empirical study on a sample of 385 subjects was conducted and the results of the study were used to answer the research problem. 